\title{
¿ES LA ÓPERA UN GÉNERO LITERARIO?
}

\author{
Juan Carlos Pueo \\ Universidad de Zaragoza
}

Aunque no lo parczca a primera vista, la cuestión puede llegar a ser controvertida, $\mathrm{c}$ incluso puede originar cierta confusión entre quienes se animan a expresar su opinión. Para demostrarlo, cito la de un reputado teórico teatral, Patrice Pavis:

Incluso si pertenecen a géneros distintos y se oponen en cuanto a su práctica escénica, su modo de financiación y de funcionamiento o su público, la ópera y el teatro están hoy más unidos que nunca, después de haberse descubierto y seducido mutuamente. La ópera cjerce una gran influencia sobre la puesta en escena contemporánea, pese a su distinta evolución [...]. Utilizando todos los medios del teatro, contando además con el prestigio de la voz y de la música, la épera representa el teatro por execlencia, un arte cuya convencionalidad y teatralidad gusta do subrayar. Arte excesivo por naturaleza, basado en las proezas vocales, realzado por el pathos de la música y el prestigio del escenario, hoy la ópera "habla" a las gentes de teatro, que le aportan la sistematicidad de una puesta en escenat y la interpretación comprometida, virtuosa y total de los actores. Gracias al trabajo fisico de los actores, que ya no son únicamente cantantes sino virtuosos y atletas efectivos, el teatro ha sabido renovar la escenificación de la ópera, antes estática, sin imaginación y exclusivamente esclava de la mâsica (Pavis, 1996: 318-319).

Este tipo de reflexiones son consecuencia de la gran polémica que, a lo largo del siglo XX, ha acompañado a la reflexión teórica y a la práctica teatral: ¿se debe considerar al teatro un género literario en la misma línea que la lírica o la narrativa, o bien se debe tener en cuenta su dimensión espectacular, que lo convertiría en otra cosa, diferente de la literatura pura y dura? Sabido es que, enfrentándose a la postura académica que había imperado hasta entonces, creadores de la puesta en escena moderna como Adolphe Appia, Vsiévolod Meyerhold, Antonin Artaud o Jerzy Grotowski -todos ellos dedicados no a la crítica académica, sino a la práctica teatral- dieron lugar a una estimación del hecho teatral que se niega a aceptar que el teatro haya de colocarse al mismo nivel que los géneros puramente literarios, ya que estos se valen de forma exclusiva del lenguaje, mientras que en el teatro la lengua hablada no es más que uno entre los diferentes 


\section{¿ES LA ÓPERA UN GÉNFRO LITERARIO?}

sistemas semióticos que lo conforman -entre los que se hallarían la gestualidad de los actores, la iluminación, el decorado, la música, etcétera- Y ni siquiera podría decirse que sca el más importante, pues existen formas teatrales como la pantomima o el ballet que prescinden por completo de la palabra sin que por ello dejen de considerarse como pertenecientes al repertorio de géneros teatrales. Puestos a buscar el principal medio de expresión en el teatro, no sería el lenguaje sino el actor, su presencia física, el que diferencia al teatro de cualquier otra actividad artística. La participación del lenguaje en el hecho teatral no pasaría de ser un hecho anecdótico.

La polémica surgió como reacción al principio de Aristóteles (Poética 1450b16-21) que ponía a la estructura verbal por encima del conjunto de los factores escénicos. Adscrita desde siempre al logocentrismo aristotélico, la crítica académica se acostumbró a olvidarse del espectáculo teatral, considerándolo tan solo una manifestación material y efímera de carácter secundario de aquello que se hallaba implícito en el texto dramático, auténtica obra de arte de la que solo se responsabilizaría al autor y en la que se hallaría en esencia todo lo que el espectáculo manifestaba de forma fugaz. La ventaja de esta consideración residía en la posibilidad de fijar, por medio de la escritura, un texto que podía considerarse así afín a otros textos literarios, los cuales, al igual que ocurre con los textos dramáticos, han sido reducidos, sin tener en cuenta sus condiciones de creación y/o recepción', a la condición de textos escritos: esto es, lenguaje fijado en una forma particular y específica que, en el caso del teatro, se caracterizaba como género literario por la preeminencia del diálogo ${ }^{2}$. Es por esta razón que la perspectiva academicista ha privilegiado el componente linguístico del hecho teatral frente a cualquier otro ${ }^{7}$. Privilegio que, a su vez, dio lugar a una especie de atrofia en el teatro burgués del XIX - el único al que se le otorgaba calidad estética dentro del panorama teatral contemporánco-, cada vez más inmerso en los enfrentamientos dialécticos de los personajes para relegar todos los demás componentes del espectáculo al campo de la ilusión naturalista, aquella que especifica que la representación debe hacerse de acuerdo con las reglas de la verosimilitud realista.

Por supuesto, las cosas son muy diferentes de las pretensiones de los críticos academicistas: incluso durante el siglo XIX caminó el teatro por sus propias sendas, sin que las pretensiones de la cultura oficial fueran lo suficientemente fuertes para eliminar lo que no se ajustase a sus modelos. No es extraño, pues, que la renovación teatral que se produjo a lo largo del siglo XX fuese acompañada por una reacción contra el academicismo imperante en la crítica para rechazar la subordinación del hecho

1.- Lo cual ha dado lugar al extendido prejuicio de que literatura es tan solo lo que está destinato a la lectura -generalmente en formato de libro. No deja de ser irónico que dicho prejuicio suponga un retorno a los orígenes del término "literatura", pero conviene no dejarse engañar, ya que este término ha adquirido en los dos últimos siglos un signilicado más amplio, referido a la dimensión poética / estética de cualquier hecho de lenguaje, independientemente de que el modo de recepción privilegiado sea hoy día la lectura en solitario. Ahí es donde yerran siempre quienes pretenden que el teatro no forma parte del conjunto "literatura", pues olvidan que este no se define por el tipo de recepción al que está destinado, aun cuando sea uno de los factores esenciales para el estudio de sus formas particulares.

2.- Se tiene en cuenta sobre todo la distinción entre una forma de discurso principal - la del diálogo- y una forma de discurso secundaria - la de las didascalias-. Se trata de una distinción de rango, pues según esta perspectiva lo esencial en el drama se hallaría siempre en el diálogo, mientras que las didascalias quedarian relegadas a un papel ancilar, meras indicaciones para ayudar a comprender lo que plantea el diálogo.

3.- $\alpha$ La preeminencia concedida al texto perdura en la teoria literaria hasta fines del siglo XIX, prácticamente hasta Artand. El teatro cra considerado por la teoría literaria como un género literario más, que se espocificaba y definía frente a otros géneros por el uso del diálogo. Esta posición, heredera del logocentrismo aristotélico, todavia persiste en la actualidad en algunos medios académicos y universitarios, y esto a pesar de la existencia en la historia de un lenguaje teatral propio y a pesar de la evolución del teatro, a partir de las vanguardias, hacia la búsqueda de formas que privilegian, a veces desde el propio texto, los componentes no verhales de lo teatral. Para Aristóteles, al que interesa únicamente el aspecto literario del teatro, lo esencial está en el texto y más precisamente en la fábula, en la forma en que el autor dispone la acción, y la catarsis debe proceder de la lectura del fexto sin necesidad del espectáculo: (Bobes Naves et al., 1995: 110-111). 


\section{JUAN CARLOS PUEO}

teatral al lenguajc, llegando al extremo de negar-caso de Artaud, entre otros muchos-toda vínculación con la literatura. La polémica entre los defensores del discurso dramático como género literario y los partidarios de la separación de teatro y literatura sigue muy vigente, porque lo que se oculta tras ella, en realidad, no es otra cosa que una lucha por controlar el sentido de la obra de arte teatral.

Dado que la literariedad del espectáculo teatral resulta incómoda a quienes están convencidos de que el teatro ha de ser "algo más" que simple y mera literatura, la semiótica del teatro ha intentado llegar a una posición de consenso que establece una distinción bastante útil entre el texto dramático, en el que solo participa el lenguaje, y el espectáculo teatral propiamente dicho, en el que participan otros sistemas scmióticos con cl mismo rango, cuando menos, que el lingǘrstico. El texto dramático no sería entonces más que el punto de partida de otro texto, emitido y percibido de forma diferente, y al que se puede denominar "texto espectacular". Puede que la distinción sirva para delimitar el campo de estudio de dos disciplinas, los estudios literarios y los estudios teatrales, que quizás se querrian ver como prácticas separadas - un autor teatral que se limitaría a trabajar en su escritorio para dejar toda la responsabilidad del montaje al director escénico, presidente a perpetuidad del club de los poetas muertos--. Sin embargo, sería un error grave considerar literatura tan solo al texto dramático con el objeto de que el texto espectacular alcance otro estatuto dentro del conjunto de las artes ${ }^{5}$. Lo literario está presente en ambos estadios de la obra, la distinción se da en la forma de recepción que ambos textos permiten o promueven: mientras que el texto dramático daría pie a una representación virtual que tiene lugar en la conciencia del lector y que, a su propia manera, sustituye a la representación teatral ${ }^{6}$, el texto espectacular se percibirá mediante una representación real en la que el/los receptor/es actúa/n como público?. Se trata, entonces, de dos formas muy distintas de acceder a un mismo objeto, cuya literariedad no se pierde en el camino que va de la una a la otra. La recepción espectacular de los textos literarios

4.- Pará una revisión del concepto "texto" aplicado al espectáculo teatral, véase Fischer-1.ichte (1979: 514-586). He optado por el sintagma "texto espectacular" frente al también común "texto escenificado" para evitar la idea de que la representación teatral no sería otra cosa que la adición de una escenificación o puesta en escena de un texto dramático que existiria previamente y en el que se hallaria in nuce todo aquello que muestra la representación. Sabido es que han existido y existen formas teatrales en las que la improvisación juega un papel escncial, hasta el punto de que no pueden considerarse únicamente consecuencia de un texto dramítico previo, que puede existir tunicamente como esquema inicial de partida o puede incluso no existir.

5. Tadeusz Kowzan, abanderado de la separación entre literatura y espectáculo, planteaba ya a finales de los 60 ulgunos reparos al respecto: «Al pasar de la literatura al espectáculo, pasamos de lo conceptual a lo imaginativo, a la pereepeión sensible. Pero el límite no estí claramente establecido. Por cjemplo, un texto comunicado oralmente contiene elementos de interpretación sensorial (voz del recitante, articulación, tono, dicción), sin que por ello sc transforme en espectáculo. Por otra parte, la tendencia a tratar el texto literario como una recitación virtual está muy extendida tanto entre los téricos actuales como en ciertas tradiciones culturales. Así, en la Grecia antigua, los pocmax se escrihían para ser rejresentados, contados o declamados. Del mismo modo, para Hegel: "las obras de poesín deben ser recitadas, cantadas o dichas, es decir representadas por una persona, como las obras musicales". Asf, pues, no es a nivel de texto donde se halla el límite entre literatura y espectículo. La diferencia entre ambos radiea en la presencia de medios de expresión que acompañan a la palabra o la sustituyen, es decir, en los elementos visuales susceptibles de ser comunicados a la vez en el espacio y en el tiempo. No hay literatura sin palabra. Eil espectáculo puede prescindir de ellas, pero no de los efectos visuales y espacio-temporaleso (Kowzan, 1970; 151). 6.- $\alpha$ Nuestro presupuesto de partida es que existen, en el interior del texto de teatro, matrices textuales de "representatividad"; que un texto de teatro puede ser analizado con unos instrumentos (relativamente) especificos que ponen de relieve los núcleos de teatralidad del texto. Estos procedimientos específicos se deben menos al texto que a la lectura que de él se hagan (Ubersfeld, 1977: 16); es decir, que en un texto de teatro, la teatralidad es siempre virtual y relativas (Ubersfeld, 1977: 46). Vẻase también Bohes Naves, 1981: 303 ,

7.- La actuación del receptor como público es esencial para la constitución del texto espectacular, como ha demostrado José Luis García Barrientos (1981: 271-294). Más que tomar un papel activo en la propia representación, la actuación del público consiste en contemplar el espectáculo, interpretarlo siguiendo un esquema hermenéutico más o menos comunitario y, a partir de ahí, dar muestras de su aprobación o su rechazo, de su comprensión o su incomprensión. de su identificación o su distanciamiento. $Y$ ya es bastante. 


\section{¿ES LA ÓPERA UN GÉNERO LITERARIO?}

es una práctica que sigue vigente en nuestros hábitos culturales, aun cuando no tenga la misma importancia que tuvo en épocas pretéritas. La mayoría de los textos literarios son susceptibles de una lectura "espectacular" - recitales poéticos, lecturas públicas de textos narrativos- hecha en voz alta, es decir, con elementos acústicos que están ausentes en la lectura individual: elevación, intensidad, duración, articulación, entonación, ritmo y resonancia. Estas lecturas tienen también la posibilidad de ir acompañadas de signos, acústicos y visuales, no lingüísticos: música, ruidos, gestos, movimientos, escenografías, iluminación, proyección de imágenes, etc., sin que cllo implique una perdida de "literariedad" en dichos textos 8

Por consiguiente, resulta difícil determinar por qué ha de considerarse el espectáculo teatral algo distinto de la literatura. Parece, más bien, que la distinción entre los dos textos, cl dramático y el espectacular, depende tan solo de la forma en que se realiza su recepeión. Con la diferencia de que, al contrario de lo que fue hasta hace algunos años la opinión imperante en los estudios literarios, el texto dramático no seria más que una manifestación incompleta, por centrarse en el texto lingúístico y dejar los demás elementos semióticos en el campo de lo virtual, de aquello que en el escenario se realiza de forma acabada. Pero no dejemos que las apariencias nos engañen: $\mathrm{el}$ texto dramático no es "más literario" que el texto espectacular. El lenguaje se halla presente en ambos casos, lo que solo puede conducir a una conclusión clara y evidente: si damos el nombre de literatura a toda manifestación del lenguaje susceptible de ser recibida, en todo o en parte, con un sentido estético", habremos de concluir que, a excepción de aquellas formas teatrales que no emplean el lenguaje -la pantomima y el ballet, mencionados arriba ${ }^{10}-$, el teatro ha de considerarse siempre como forma literaria. Eso sí, con unas características concretas que lo diferencian de las demás manifestaciones.

Desde este punto de vista, la cuestión planteada en el título de este artículo no debería plantear ninguna duda: puesto que el lenguaje forma parte de los sistemas semióticos que participan en la ópera, no creo que deba haber ningún inconveniente para considerar a esta un género literario, diferenciable de otras formas que se incluyen dentro de la categoría o macrogénero "teatro"1. La hipótesis se enfrenta, no obstante, a ciertas reticencias que, si bien no han sido expresadas de forma

8. Ignoro por qué estas formas de recepción de textos literarios carecerian de un carácter espectacular, al igual que cualquier función de teatro o de circo, concierto musical o acontecimiento deportivo, nos hallamos ante una o varias personas que, por las razones que sean, se presentun ante un público para realizar algún tipo de actividad que consideran digna de ocupar el ocio de este. Consideraciones como la profesionalidad de los recitadores, la clase de compensación económica que estos puedan recibir por su esfuerzo, el precio que se exige al público por su asistencia, la dimensión intelectual del acto llevado a cabo, el espacio donde se realizan estas actividades, ctcétera, me parecen irrelevantes desde el momento en que el espectáculo teatral se ve libre de toda restricción en lo que se refiere a cualquiera de estos factores (para un planteamiento más exhaustivo de la cuestión, véase García Barrientos, 1981: 255-271).

9.- Esto es, al menos, lo que se desprende de la definición que da al término Maria Moliner en su Diccionario de uso del español: aArte que cmplea como medio de expresión la paiabra hablada o escritas -véase n. 1-.

10.- Y, aun así, todavía se puede plantear alguna duda, ya que el texto espectacular de estas formas puede tener, como ocurre con el Acto sin palabras de Samuel Beckett, su base previa en un texto dramático en forma de libreto en el que los signos dramáticos se trasladen a un lenguaje más o menos literario, caracterizado en este caso por su adscripción a los territorios de la ficción. L cjos de mí la intención de deducir de este dato la "literariedad" de estas formas teatrales, caracterizadas en el momento de su representación por la ausencia de signos linguíisticos. Este apunte solo tiene la intención de resaltar el nexo que tienen - o que pueden tener- con la literatura.

11.- «Una de las cuestiones más controvertidas en la teoría de los géneros literarios es la de los niveles de abstracción que deben ser considerados y claramente distinguidos para evitar posibles confusiones. Muchos autores dan hoy por detinitivamente zanjada esta problemática con el deslinde entre géneros teónicos (o naturalex) y géneros históricos. Con la primera denominación se alude a categorías abstractas y universales que responden a una característica antropológica, mientras que la segunda se reserva para hacer referencia a las distintas manifestaciones históricas, empiricas, que se derivan de esas abstracciones iniciales. Se derivan: es decir, que los géneros históricos son actualizaciones o concreciones coyunturales de los géneros naturaless (Viñas Piquer, 2005: 291; en cursiva en el texto). 


\section{JUAN CARLOS PUEO}

categórica, sí han dado lugar en la crítica literaria a una consideración hacia la ópera que, salvo excepciones, no diré que haya sido despectiva, pero sí indiferente en lo que se refiere a sus valores literarios e incluso dramáticos. Si volvemos de nuevo nuestra mirada a la crítica académica, no nos sorprenderá esta actitud. La ópera privilegia el lenguaje musical, lo cual deja al lenguaje literario en una posición que resulta demasiado incómoda: cuando menos, el lenguaje estará al mismo nivel que la música, pero nunca por encima de clla. Fl prejuicio más generalizado, consecuencia del logocentrismo que ha presidido las relaciones entre literatura y música, sostiene que el primero está al servicio de la segunda, motivo por el que se halla despojado de las que, según la Modernidad, deberían ser las características principales de todo texto literario: originalidad, espontaneidad y libertad. Se tiende a pensar que los libretos operísticos carecen de estas cualidades y, por consiguiente, deben ser considerados literatura de segundo orden, accesoria o menor, indigna de la atención que se ofrece a la literatura en que el lenguaje ejerce una posición de preeminencia y dominio absoluto.

No faltan razones para explicar esta actitud: históricamente, la ópera ha mostrado sícmpre una falta de originalidad e invención que la convierten en un perfecto catálogo de versiones, adaptaciones y recreaciones de temas tratados previamente. Durante los siglos XVII y XVIII esto no tendría la menor importancia, puesto que la imitación de modelos anteriores no solo cra práctica habitual, sino que formaba parte de las reglas impuestas por la preceptiva clásica, aplicables al teatro en su totalidad. No obstante, la ópera de los siglos XIX y XX ha seguido practicando el arte de la adaptación de novelas y dramas. $\mathrm{Y}$ aunque estos no hayan sido necesariamente los más antiguos ni los mejor valorados, lo cierto es que el canon operístico parece depender excesivamente del canon literario no musical ${ }^{12}$. Esta costumbre ha hecho que se vea la ópera, desde el punto de vista literario, como una práctica intrascendente que ha ido siempre a la zaga de las producciones verdaderamente originales de la literatura, que eran las que iban abriendo camino.

En relación con esta característica, habría que señalar también el hecho de que la ópera-como todo el teatro musical- ha sido durante mucho tiempo un espectáculo dirigido a las masas ${ }^{13}$, lo que ha hecho que se pliegue a todo tipo de convencionalismos temáticos y formales sin otra intención que la de "dar gusto" a un público acostumbrado a digerir esquemas arquetípicos conocidos de antemano, de los que la ópera solo habría podido deshacerse al precio de convertirse en un arte minoritario. Esto ocurre cuando surgen los adalides de un teatro que, en lugar de halagar a las masas, debe dedicarse a formarlas, $y$, sobre todo, cuando, ya en el siglo XX, aparecen el cine, la radio y la televisión, los únicos que conseguirán hacer del teatro un espectáculo para minorías ilustradas. Así pues, debemos tener en cuenta que la ópera fue considerada durante mucho tiempo una manifestación literaria más bien trivial -a lo que no es ajeno el proceso de vulgarización de otros textos al que me he referido en el párrafo anterior-, $\mathrm{e}$ indigna de atraer la atención de una crítica centrada en las "grandes obras", actitud que, en lo que se refiere a la consideración específicamente teatral -no así cn la musical-del espectáculo operístico, no ha desaparecido por completo.

Más importante, sin embargo, es la idea de que la estructura musical cjerce una presión excesivamente fuerte sobre el lenguaje literario. Este debe plegarse a las exigencias del compositor,

12.- Homero, Euripides, Ovidio, Séneca, Tácito, Troyes, Ariosto, Tasso, Cervantes, Shakespeare, Corneille, Molière, Prévost, Schiller, Goethe, Scott, Hugo, Melville, Tolstoi, Henry James, Thomas Mann, Tennessee Williams, por enumerar tan solo a los más importantes. A ellos hay que añadir muchos otros nombres que ocupan en el canon una posición más modesta; Gozzi, Beaumarchais, García Gutićrrez, Scribe, Merimée, Dumas hijo, Murger, Sardou...

13.- Me refiero fundamentalmente a las tradiciones operísticas de cada país, por supuesto. El teatro musical ha sido un fenómeno de masas siempre que la lengua empleada ha sido la de los asistentes a la representación - lo cual es lógico, pues el público siempre prefiere que se le cante en su propio idioma-. Sin embargo, cabe recordar la hegemonía que tuvieron los cantantes durante el siglo XVIII, que liegó hasta el punto de que a ciertos sectores del público no les importaba el idioma en que cantasen -el cual solía ser el italiano, siempre que se supieran valer de los códigos adyacentes -sobre todo el lenguaje gestual-, que les permitían saber qué era lo que se estaba cantando. Ahora bien, cuando estos códigos fucron sustituidos por los códigos de representación naturalista, se hizo necesario que la lengua en que se representaba la ópera fuese la del público congregado en el teatro, Lo cual tuvo lugar precisamente al mismo tiempo que se producía el desarrollo de las escuelas nacionalistas de ópera. 


\section{¿ES LA ÓPERA UN GÉNERO LITERARIO?}

que modificará el libreto siempre que lo considere conveniente, al objeto de que su creación resalte por encima de la de su libretista. El lenguaje literario se hallaría, por tanto, sometido a las exigencias de la música, y el libretista se vería obligado a renunciar a toda posibilidad de expresarse por medio de la ópera. Semejante escritor no sería así más que un artesano del lenguaje encargado de facilitar la labor de los músicos -compositor, director de orquesta, cantantes-, verdaderos artífices y responsables últimos de la obra final. De ahí que el lenguaje literario se vea obligado a "servidumbres formales" como la rima y el metro, elementos que, por lo demás, no se emplean libremente, sino que están al servicio de la música. La ejecución de una ópera se basa en premisas que atentan no solo contra el prejuicio naturalista -característico, como señalé arriba, del teatro burgués del XIX--, sino contra toda pretensión de verosimilitud y coherencia en el orden pragmático; el canto impone una serie de condiciones que no solo afectan a la entonación, sino también a la duración de las sílabas, que deben mantenerse bajo la férula de un ritmo diferente al del lenguaje hablado, cuando no se pierden en adornos y melismas que retardan la progresión del diálogo.

Todo esto repercute de forma directa sobre el tipo de recepción que se puede hacer del texto dramático, Si se afronta la lectura del libreto de la misma manera que cualquier otro texto destinado a la escena, el lector tiene la impresión de que se le escamotea algo: la representación virtual que tiene lugar en su conciencia queda incompleta en la lectura, pues lo cierto es que el elemento musical no puede ser leído de la misma manera que las palabras. Esto sucedería así incluso en el caso de que tuviéramos la partitura y fuéramos capaces de leerla en toda su complejidad, con la inclusión del acompañamiento instrumental -habilidad que se me antoja bastante improbable, dado que la lectura se produce linealmente, un signo detrás de otro, mientras que las combinaciones armónicas de sonidos musicales han de producirse de forma simultánea-. La representación virtual que propicia el texto dramático parece imposible en el caso de la ópera, de modo que la mera lectura de un libreto puede entenderse como un cjercicio estéril del que se nos escapa aquello que la ópera tiene de esencial'4. Téngase en cuenta además que hoy día existe la posibilidad de escuchar una ópera -en concierto, en retransmisión, en disco-liberada de todos los demás signos que intervienen en la representación, incluido el lenguaje, bien porque el oyente no entiende la lengua en que se halla la ópera, bien porque prefiere dejar de lado los significados lingúísticos para centrarse en los contenidos musicales. En ambos casos, nos encontramos ante una recepción estrictamente musical de la obra, similar a la que se produciría si el espectador que asiste a la representación cerrase los ojos y decidiese dedicar su atención tan solo a la música. Actitud perfectamente respetable si a uno no le interesa otra cosa y que, evidentemente, no tienc nada que ver con lo literario ${ }^{15}$.

14.- Ën realidad, esto ocurre siempre que leemos cualquier texto teatral, ya que la lectura nunca puede sustituir at la experiencia de asistir a una representación: dicho de forma más general, y en términos de Pero Grallo, lo virtual no puede sustituir a lo real, se mire por donde se mire. Lo que pasa es que, en el caso de un libreto de ópera, esta distancia entre lo virtual - la lectura- y lo real - la representación- so hace más evidente, y no nos queda más remedio que reconocer nuestro fracaso, la lectura de una comedia, en cambio, puede producir la ilusión de que el simulacro producido en nuestra conciencia lectora es suficientemente eficaz para darnos una idea de lo que esa comedia significal,

15.- Aun así, numea faltan mentes bienintencionadas convencidas de que la escucha musical suple todo lo que pueda decirse con el lenguaje, de forma que no hay necesidad de entender la letra para apreciar en su totalidad lo que la representación operistica expresa. Atenderé a la cuestión del significado musical más adelante, pero digo yo que, si st pudiera prescindir del lenguaje en la ópera, no habria ninguna necesidad de libretos, que podrían sustituirse con camelos, sear o simples vocalizaciones de los cantantes. $Y$ si se me objetara que eso no podria ser porque el significado musical va asociado al valor fónico del lenguaje, aunque prescinda de su valor semántico, no me quedaria más remedio que aducir la inseparabilidad que preside las relaciones entre significante y significado, la cual no queda abolida porque el primero sirva de soponte a la música. Nos guste o no, la presencia de un significante va automáticumente asociada a la de su significado -otra cosa es el complejo juego de denotaciones y connotaciones que se suscita a partir de esta relación y de las que mantiene el signo en su totalidad con otros signos-. 


\section{JUAN CARLOS PUEO}

Si bien numerosos, los argumentos expuestos no me parecen suficientes para rechazar la opción de una representación virtual a partir tan solo del texto dramático del libreto, aunque es preciso reconocer que dicha representación será todavia más insatisfactoria que la que procede de un texto dramático perteneciente al teatro hablado. Al fin y al cabo, la lectura de un libreto pucde hacerse de la misma manera que la de cualquier otro texto dramático, aun teniendo presente la ausencia del componente musical. Por supuesto, el lector habrá de tener en cuenta que la representación virtual pierde un clemento importante a la hora de enfrentarla al texto espectacular, a no ser que conozca la música a la perfección y la haya memorizado, aplicándola así a su lectura, o bien simultanec esta con la audición de la música en versión discográfica, radiofónica o concertística, en cuyo caso podremos hablar de lectores aventajados frente a aquellos cuya competencia para enfrentarse al texto en cuestión es menor. Pero ni aun así estaríamos en posición de negar la pertinencia de una lectura que prescinde del componente musical. El texto dramático que encontramos en el libreto operístico presenta las mismas características que cualquier otro texto dramático, y eso debcría ser razón suficiente para garantizar la literariedad dicho texto, por las razones expuestas arriba ${ }^{16}$. Como puede verse, todo depende de la actitud con que nos dispongamos a la recepción de dicho texto. Opciones no faltan.

Con todo, si queda demostrado que en la ópera el texto dramático puede ser considerado literatura, no ocurre to mismo con el texto espectacular. Las reticencias a las que aludía al comienzo de este trabajo-cuando no se trataba de una oposición abierta-sc hacen más relevantes por $\mathrm{el}$ hecho de que en la lectura del texto dramático se puede prescindir de la música, mientras que su escenificación no permite tamaño despropósito ${ }^{17}$. Pero ya se ha visto que, a pesar de las objeciones de quienes todavía defienden la idea de que el teatro - en su escenificación- no ha de considerarse literatura, la teoria literaria actual parece estar de acuerdo en que texto dramático y texto espectacular no son sino las dos caras de una misma moneda. Así pues, tampoco hay motivos suficientes para descartar la literariedad del texto espectacular en la ópera, pues, hablado o cantado, cl lenguaje sigue siendo un elemento básico, sin el cual no se podría dar sentido a la representación, a no ser esta se adscriba a aquellos géneros en los que no participa el lenguaje. Si consideramos que el teatro hablado - tanto en la forma del texto dramático, como en la forma del texto espectacular-es literatura, habremos de concluir que el teatro cantado también lo es. No veo por qué habría de hacerse una distinción de rango al respecto cuando $\mathrm{en}$ el dominio de la poesía lírica sí que somos conscientes, o al menos deberíamos serlo, de la estrecha relación entre texto y música: pues un poema lírico no dejará de scrlo por haber sido compuesto para ser cantado - de hecho, conviene recordar que el poema destinado a la mera lectura no es sino una pequeña parte de la tradición poética, que casi siempre ha tenido a la músíca como compañera de viaje-.

\footnotetext{
16. - M. ' del Camen Bobes Naves ha dedicado muchos de sus trabajos (véase Bobes 1981, 1987 y 1988 ) a demostrar la pertinencia de un estudio autónome del texto dramático. Valga esta cita para dar cuenta de la literariedad de este tipo de textos, entre los que pueden y deben incluirse los libretos operísticos: $\alpha$ El texto lingä́stico tiene, pues, una doble existencia: precede a la representación y la realiza. Como texto que precede a la representación puede leerse como una obra literaria e interpretar los diálogos como expresión de una fábula, y bajo esa consideración, el dramia se somete a las leyes de "sucesividad" de toda lectura, literaria o no, impuestas por los signos linguíisticos. Esta sucesividad es inexorable, se da en la escritura, se da en las relaciones de la fábula, cuyos motivos se sitúan en tiempo sucesivo, y se da en la lectura. Pero el texto teatral es más que una fábula y es más que unos signos linguisticosa (Bobes Naves, 1981: 302-303).

17. - Solo a modo de curiosidad se puede citar la broma con que planteó Pedro Muñoz Seca la escenificación de su astracanada Los extremeños se tocan: como los músicos de la orquesta se han declarado en huelga, los actores se limitan a recitar en el momento que les corresponde los numeros musicales de la frustrada zarzuela. Pero es que el despropósito forma parte de la estética astracanesca, lo cual hace más palmaria la certeza de que sin música no puede haber en la ópera -ni en sus formas afines- texto espectacular, como no podría haherlo sin actores o sin iluminación.
} 


\section{¿ES LA ÓPERA UN GÉNERO LITERARIO?}

Ahora bien, si loque se pretende es incluir a la ópera dentro del sistema literario, habrá de hacerse desde su relación con las restantes formas teatrales, para lo cual será necesario volver la mirada hacia la teoría de los géneros literarios. El sistema de géneros se nos ofrece como una taxonomía capaz de incluir en un orden satisfactorio todas las manifestaciones textuales que agrupamos bajo el marbete de "literatura". A pesar de ello, no parece haber un consenso explícito sobre los criterios que han de emplearse para que esta tipología pueda utilizarse de forma universal. Los criterios temáticos conviven con los formales, los históricos, los axiológicos, etc. Esta falta de consenso ha hecho que se abandone todo intento de establecer una taxonomía universal razonada, si bien la clasificación que surge en Europa a partir del siglo XVI y que se afianza con el Romanticismo división tripartita entre lírica, narrativa y teatro, con sus derivaciones particulares para cada una de estas tres categorías- sigue empleándose sin que apenas se derive de ella problema alguno: todo el mundo puede distinguir una novela entre otros textos, aunque nadie sca capaz de definir con total precisión en qué consiste el género "novela". En otras palabras, parece que cn teoría la ordenación genérica de la literatura es una causa perdida, mientras que en la práctica, mantiene una presencia indiscutible alli donde se hace necesaria no tanto una ordenación como una distinción entre las diferentes formas que pueda adoptar el hecho literario ${ }^{\text {In. }}$.

El caso del teatro es paradigmático, pues ofrece unas características que están ausentes de cualquier otra modalidad literaria: en principio, puede decirse que todo texto escrito para ser representado es teatro -que esto ocurra en el ámbito espectacular de una práctica social específica o cn otros ámbitos donde se practican modos de recepción alternativos, a los que aludiré más adelante, es indiferente-- 1 a distinción respecto a otras formas litcrarias es palmaria, y, en principio, no hace falta recurrir a Aristóteles para subrayar algo tan sabido. Aun así, resulta difícil llegar a un acuerdo cuando se trata de distinguir los diferentes géneros que conforman el conjunto de los textos teatrales, y la cosa se complica aún más al incluir en el cuadro las que llamaré "formas dramático-musicales". Con todo, intentaré aportar algo de luz al asunto.

Para empezar, no estará de más recordar que, como ha indicado Gérard Genette (1979), la clasificación genérica tradicional es fruto de un gigantesco equívoco por parte de los comentaristas de Platón y Aristóteles, equívoco que, si bien se afianza en el XIX, empicza a cuestionarse en la segunda mitad del siglo XX. Uno de los problemas con que se enfrenta la teoría de los géneros que intenta adaptar la propuesta aristotélica a la literatura posterior la encontramos en la forzada dualidad del esquema, que atiende a condiciones temáticas -dado que la poesfa es imitación, ¿qué es lo que imita? - y modales - ¿cómo, o, más concretamente, bajo qué situación de cnunciación lo imita?-. Partiendo de estas últimas, la teoría tradicional de los géneros se asienta en la diferenciación entre enunciación narrativa y enunciación dramática, teniendo presente que el rasgo más sobresaliente de esta última sería, como ya se ha apuntado arriba, su carácter espectacular ${ }^{19}$. No obstante, debemos tener en cuenta que este carácter no es exclusivo de la enunciación dramática, ya que cualquicr recital o lectura pública añaden un componente espectacular a la recepción de los textos de que

18.- - f a clause ou l'écluse du genre déclasse ce qu'elle permet de classer. Elle sonne le glas de la généalogie ou de la généricité auxquelles elle donne pourtant le jour. Mettant à mort cela même qu'elle engendre, elle forme une étrange figure, une forme sans forme, elle reste à peu près invisible, elle ne voit pas le jour ou ne se donne pas le jour. Sans elle il n'y a ni genre ni littérature mais dès qu'il y a ce clin d'ceil, cette clause ou cette écluse de genre, à l'instant même où s'y entament un genre ou une littérature, la dégénérescence aura commencé, la fin commences (Derrida, 1980: 265).

19. - La cuestión ha sido largamente debatida en el ámbito de la teoría de los géneros: presentación directa en el texto del discurso de los personajes versus mediación de un nurrador para situar dicho discurso. Sin embargo, teniendo en cuenta lo dicho accrea de la dualidad entre el texto dramático y el texto expectacular, una clasificación genérica busada en esta dicotomía resulta tan problemática como insatisfactoria, pues nos llevaria a colocar en el mismo género, junto a los textos específicamente teatrales, otros tipos de textos que apenas tienen que ver con el teatro, como el dílogo filosófico o la novela dialogada. Bastante complicada está ya la cuestión como para añadirle otros elementos de confusión. 


\section{JUAN CARLOS PUEO}

son objeto, si bien no lo hacen de forma tan intensa como la que se propone en la representación teatral. La dimensión espectacular de la enunciación dramática se da a partir de dos rasgos que la diferencian de cualquier otro tipo de enunciación.

El primero de ellos es la presencia de un mediador entre el texto - al que sirve de soporte- y el receptor - que se convierte así en espectador-, Dicha presencia es esencial, y se convierte en la base de toda definición del teatro, como la elemental que ofrece Eric Bentley (1964: 146) y que reproduzco según la cita Erika Fischer-Lichte $(1983 ; 27)$ : «El teatro reducido a sus mínimas condiciones previas, necesita a una persona $\mathrm{A}$, que presenta a $\mathrm{X}$, mientras $\mathrm{S}$ es espectadon. $\mathrm{La}$ ventaja de una definición así es que no se necesita determinar los medios empleados para que A presente a $\mathrm{X}-\mathrm{A}$ puede ser un actor, pero también una marioneta o un títere- $\mathrm{y}$, en la cuestión que nos ocupa, tampoco necesita determinar los medios empleados para que $\mathrm{S}$ conozca a $\mathrm{X}$ y a sus circunstancias -que es, al fin y al cabo, de lo que se trata-.

Sin embargo, este rasgo no es suficiente para determinar la naturaleza del hecho teatral. Si la presencia de un mediador que presenta a un personaje ante el público fuese suficiente, podríamos incluir dentro de la categoría de espectáculo teatral a las lecturas dramáticas ${ }^{\circ}$, las cuales, siendo una forma de reccpción espectacular, no liegan a adquirir la condición de espectáculo teatral. Habitualmente, la práctica teatral ofrece al espectador la presentación con actores u objetos en un escenario -del tipo que sea- y que van desarrollando una peripeciat que exige, por encima de toxlo, la presentación de una cadena de significados que vendrán dados at través de diversas instancias, las cuales han sido asumidas por la tradición hasta el punto de formar distintos códigos semióticos ${ }^{2 \pi}$, algunos de los cuales son visuales -los referidos al aspecto y a los movimientos de los personajes, así como los estrictamente espaciales, como el decorado y la iluminación-, mientras que otros son auditivos - Ienguaje, música y efectos sonoros-.

Aunque se ha intentado asociar determinados elementos visuales con algunas clasificaciones genéricas -me refiero a los diseños de Sebastiano Serlio para la tragedia, la comedia y el drama satírico, adoptados por la preceptiva clasicista-, lo cierto es que solo los signos linguísticos y musicales han logrado el suficiente prestigio para dar pie a definiciones genéricas basadas en la ausencia o presencia de estos medios -drama, pantomima, ópera, ballet-. Por el contrario, la presencia o ausencia de signos de carácter visual remite únicamente a formas de recepción más o menos espectacular, lo que hace que el espectáculo teatral quede definido por la presencia de un mediador que, siendo el soporte necesario para la representación ante el espectador, se caracteriza además por su capacidad de movimiento: la mímica, los gestos y las distintas posiciones que el

20.- "Lectura dramática" me parece el término más adecuado para designar esa actividad cultural ejercitada por ciertos grupos de actores y actrices - aficionados, por lo general-que se reúnen no para representar un texto dramático, sino para leerlo en posición estática ante un público que accede así a una forma de recepción a medion camino entre la lectura individual y la representación teatral. Evidentemente, se trata de un modo de recepción que, si bien no carece de una dimensión espectacular, ha de distinguirse de la representación por las razones que aduciré seguidamente. Pero también ha de tenerse ca cuenta que no se trata de una práctica novedosa, y que siempre ha estado vinculada con el teatro hasta el punto de tomar muchas veces su nombre; piénsese en el teatro elegíaco medieval de ámbito universitario, o en el teatro radiofónico del siglo XX.

21.- Tras muchos debates, la clasificación definitiva de todos los códigos teatrales viene de la mano de Tadeusz Kowran (1968: 132-145), quien señala la existencia de trece eódigos que pueden adoptar varias combinaciones sin que pueda establecerse una ley universal que determine la primacía de uno de ellos sobre los demás: palabra, tono. mímica, gesto, movimiento, mąuillaje, peinado, vestuario, accesorios, decorado, iluminación, música y efectos sonoros, Se han propuesto algunas matizaciones a esta clasificación: por cjemplo, Erika Fischer-Lichte (1983: 143. 161) propone reemplazar el término "maquillaje" por el de "máscara" para referirse no solo a los cambios que el actor puede realizar en su aspecto, sino a su presencia física, modificada o no, generadora por sí sola de signos teatrales que funcionan como indices de la edad, cl sexo, la raza, el estado de salud e incluso la posición social del personaje. También aniade a la lista de Kowzan (1983: 197-206) la concepción del espacio-forma del edificio teatral en el que tiene lugar la representación. Y también ha de señalarse el hecho de que no todos los teóricos del teatro aceptan la necesidad de reducir los códigos teatrales a una lista como la que propone Kowran. 


\section{¿ES LA ÓPERA UN GÉNERO LITERARIO?}

actor ocupa en el escenario son los factores decisivos que separan el hecho teatral de cualquier otra forma de recepción del texto dramático -caso de las lecturas dramáticas- o de cualquier forma de recepción espectacular a que se vea sometido un texto no dramático-como ocurre en los recitales poéticos o en las lecturas ante público de textos narrativos ${ }^{-22}$.

Todo esto es aplicable a los géneros dramático-musicales. Los textos operísticos son creados con la intención de que al menos una persona $\mathrm{A}$ presente a $\mathrm{X}$ ante el espectador $\mathrm{S}$, y en la representación subsiguiente no solo se tienen en cuenta los códigos auditivos, sino también los visuales, empezando por aquellos que implican algún tipo de movimiento por parte de los cantantes-actores ${ }^{23}$. Desde su pertenencia al modo de enunciación dramática, no puede establecerse ninguna diferencia entre las formas dramático-musicales y las formas dramáticas del teatro hablado tradicional - en que la música no tiene tanta relevancia-. Tan solo nos permite incluir ambas formas en un mismo grupo, categoría o macrogénero, el del teatro, que se diferencia de los otros grandes conjuntos genéricos, el lírico, el narrativo y el argumentativo.

Tras la distinción entre modos de enunciación, la clasificación genérica tradicional se ocupa de los objetos de imitación: dentro del modo de enunciación dramática, este criterio permitió a Aristóteles trazar la diferencia entre tragedia y comedia, según la práctica teatral de la Atenas del siglo IV a. de C. Aunque las cosas han cambiado bastante en estos veinticinco siglos, la frontera entre dos clases de géneros dramáticos, los serios y los cómicos, sigue estando presente en todas las clasificaciones genéricas, $y$ ha tenido un papel destacado a la hora de establecer una clasificación de géneros dramático-musicales: es en el siglo XVIII cuando se cstablece la distinción entre ópera seria y ópera bufa o cómica, distinción que, evidentemente, obedece al esquema clásico que determina que los dos grandes géneros del teatro hablado son la tragedia y la comedia. No obstante, esta distinción ha ido cayendo en el olvido a partir del XIX, no solo porque se hayan dejado de producir tragedias, también porque han ido surgiendo nuevos géneros que han hecho inviable el esquema aristotélico al no someterse a sus preceptos. Lo mismo ha ocurrido con la ópera, que fue abandonando paulatinamente los esquemas que propiciaba la división entre ópera seria y ópera cómica para adoptar otros más acordes con la sensibilidad propia de la Modernidad.

Con todo, la clasificación aristotélica según el objeto de imitación no hace sino adelantar acontecimientos, pues antes de distinguir los subgéneros operísticos habría que resolver el

22. - EI l movimiento [... ] se halla vinculado en todos los casos a aquella instancia, viva o no, corporal que se convierte de un modo u otro en centro de la escena. En todo caso, a pesar de que [... \} existen diferencias [... . sobre el modo de alcanzar un ideal de escena, se llega a una misma conclusión final, es decir, el movimiento expresa los sentimientos ocultos, lo inexpresable. Aunque se tenga en cuenta aquel como algo que trasciende al propio cuerpo que lo cjecuta. éste - el cuerpo-surge en definitiva como traductor de sentimientos, como elemento con una capacidad de evocación simbólica. Movimiento y cuerpo aparecen como sustitutivos de la palabra en la escena -incluso aunque no se llegue a prescindir de ella para el espectículo- a la hora de evocar los sentimientos del almas (Sánchez Montes, 2004: 183).

23.- Eisto deja fucra de los géneros dramático-musicales al oratorio, género musical caracterizado por proponer un texto similar al texto dramático como punto de partida, aun cuando ese texto no es objeto de una representación teatral, sino que ha de cjecutarse necesariamente en forma de concierto, esto es, estáticamente. Para ellocuenta con un narrador-testo-que dedica sus intervenciones a la descripción de escenas y el relato de acciones. A pesar de cumplir la exigencia de que varias personas presenten cierto número de personajes ante el espectador, la ausencia de mímica, gestos y movimiento por parte de esas personas y la presencia del festo, que reemplaza con sus intervenciones todo lo que en el teatro se presenta mediante los códigos visuales, implica una renuncia por parte del género musical a la espectacularidad especificamente teatral, Con todo, es preciso señalar que en el siglo XVII, los primeros oratorios tuvieron las mismas caracteristicas de la ópera, esto es, la representación en escenarios con vestuario, caracterización y, sobre todo, movilidad de los actores: la única diferencia respecto a la ópera residía en que el oratorio trataba un tema religioso-solo a pautir del XVIII se comenzó la composición de oratorios de tema profano-. Sin embargo, ya a mediados del XVII se habia producido el cambio hacia una representación estálica, que hace del oratorio una género completamente diferente de la ópera y formas afines. 


\section{JUAN CARLOS PUEO}

problema de la distinción entre el teatro hablado y el teatro cantado. $\mathrm{Y}$ el gran problema de la clasificación genérica tradicional es que tiende a considerar únicamente dos de los factores planteados por Aristóteles, el modo y el objeto de enunciación. Pues hay además una tercera posibilidad, la formal, que Aristóteles planteó al comienzo de la Poética y a la que, debido probablemente a la pérdida de buena parte del texto, pero también a la propia evolución de la teoría literaria, no se ha hecho mucho caso: me refiero a la clasificación basada en los medios de imitación - dado que la poesía es imitación, ¿en qué,o, más concretamente, de qué manera imita?-. La clasificación según los medios de imitación ha sido frecuentemente olvidada a la hora de justificar un esquema de géneros literarios que, sin embargo, nunca ha perdido de vista la clasificación según los modos y los objetos de imitación ${ }^{24}$. Sin embargo, la cuestión de los géneros teatrales encuentra una solución adecuada solo con que se atienda al esquema propiciado por el estagirita:

Pues, asf como algunos con colores y figuras imitan muchas cosas reproduciendo su imagen (unos por arte y otros por costumbre), y otros mediante la voz, así también, entre las artes dichas, todas hacen la imitacion con el ritmo, el lenguaje o la armonfa, pero usan estos medios separadamente o combinados; por cjemplo, usau sólo armonía y ritmo la aulética y la cítarística, y las demás que puedan ser semejantes en cuanto a su potencia, como el arte de tecar la siringa; y el arte de los danzantes imita con el ritmo, sin armonía (éstos, en efecto, mediante ritmos convertidos en figuras, imitan caracteres, pasiones y acciones).

1... Pero hay artes que usan todos los medios citados, es decir, ritmo, canto y verso, como la poesfa de los ditirámbicos y la de los nomos, la tragedia y la comedia. $Y$ se diferencian en que unas los usan todos al mismo tiempo, y otras, por partes.

Éstas son, pues, las diferencias que establezco entre las artes por los medios con que hacen la imitación (Poética, 1447a19-1447b29 [García Yetra, ed., 1974: 127-130]).

Por supuesto, la literatura, la música y la danza han evolucionado lo suficiente para que resulte imposible encadenarnos a una interpretación estricta del sistema de géneros aristotélico -cuestión que ya planteaba numerosos problemas a los comentaristas del XVI, y que les llevó a plantear la primera reformulación de la teoría de los géneros-. Con todo, la distinción entre los distintos medios empleados junto con el lenguaje podría ser útil para determinar, cuando menos, la filiación de algunas formas artísticas que, al igual que los géneros "estrictamente" literarios, participan de su adscripción a lo que se ha venido llamando modos o formas naturales - poema, relato, drama y argumentación-, los cuales podrían caracterizarse como universales y espontáneos - esto es, no dependientes de la tradición ni restringidos al ámbito de la literatura-. Se trata, sencillamente, de una apelación al sentido común que permitiría justificar teóricamente lo que en la práctica viene siendo habitual cuando se aplican instrumentos críticos similares al análisis de, por ejemplo, formas del relato literarias como el cuento, la epopeya y la novela, y no literarias como el cómic, la fotonovela y el cine-formas de expresión en las que no siempre participa el lenguaje, y que, por lo demás, tampoco limitan su alcance al modo "relato"--.

En el caso que nos ocupa, dado que la preeminencia de los códigos visuales -en especial la mímica, los gestos y el movimiento de los actores- es lo que diferencia a los géneros teatrales de

24.- - Aristote distingue en principe, dans le premier chapitre, trois types de différenciation entre les arts d'imitation: par l'objet imite et le mode d'imitation 1...). mais aussi par les emohiness (trad. Hardy; littéralement, e'est la

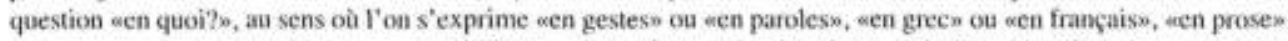
ou een verss, een hexamètres» ou aen trimètress, etc.): e'est ce dernicr niveau qui répond le mieux à ce que notre tradition nomme la forme. Mais it ne recevra aucun investissement véritable dans la Poétique, dont le système générique ne fair à peu près acception que d'objets et de modesa (Genette, 1979: 17-18; en cursiva en el texto). 


\section{¿ES LA ÓPERA UN GÉNERO LITERARIO?}

las restantes manifestaciones literarias, se puede proponer una clasificación basada en la presencia o ausencia de los códigos auditivos más importantes, el lenguaje ${ }^{25}$ y la música. Es preciso aclarar que, al incluir como uno de los factores en juego la ausencia de los signos lingüísticos, la clasificación no atiende únicamente a los géneros literarios, sino que se aplica a todos los géneros teatrales, incluyendo los no literarios. Así pues, la combinación de estos dos factores, la música y el lenguaje, dará lugar a las cuatro posibilidades expuestas en el siguiente esquema:

\begin{tabular}{|c|c|c|}
\hline & + Lenguaje & - Lenguaje \\
\hline+ Música & Ópera & Ballet \\
\hline- Música & Drama & Pantomima \\
\hline
\end{tabular}

La única excusa para no aceptar esta clasificación vendría del logocentrismo militante de una teoría que sigue aceptando como dogma de fe que el teatro es esencialmente un acto de lenguaje. Tradicionalmente se acepta el drama como término no marcado que engloba a todas las restantes manifestaciones teatrales, si es que no se sitúa por encima de ellas ${ }^{26}$. La ausencia de lenguaje marca como géneros no literarios al ballet y a la pantomima, mientras que la ópera suele aparecer marcada como género musical. Sin embargo, el logocentrismo plantea un problema demasiado grave para una teoría del teatro que ha modificado drásticamente la jerarquía de los códigos semióticos que participan en el espectáculo teatral. En primer lugar, porque si se acepta la primacía en el texto espectacular de los códigos visuales referidos a la mímica, los gestos y el movimiento de los actores, se hace evidente que la ausencia de lenguaje no puede ser un criterio válido para marcar los géneros del ballet y la pantomima. Por el contrario, el género no mareado habría de ser la pantomima, dado que prescinde de los códigos auditivos, por ser medios de imitación, o mejor, expresión, de carácter secundario, y se queda con lo esencial, la presencia física y el movimiento del actor. $\mathrm{Y}$ en segundo lugar, porque aun aceptando la capacidad de los códigos auditivos para ofrecer una clasificación genérica según los medios de expresión - lo que no invalidaría la primacía de los códigos visuales, solo se limitaría a dejarlos provisionalmente a un lado-, tampoco queda claro por qué la música habría de ocupar una posición tan preeminente como para borrar la literariedad no del texto dramático - pues sería imposible-, pero sí del texto espectacular. Aplicado a la clasificación según el esquema de los medios de expresión, el logocentrismo que haría del drama el género no marcado para convertir a los demás en géneros no literarios sigue siendo la principal traba con la que choca la teoría del teatro contemporáneo, cuyos presupuestos se

25.- Los cócligos lingïísticos que intervienen en el teatro son, en la temminologia de Kowran (1968: 132-134), la palabra y el tono, mientras que Fischer-Lichte (1983: 45-68) prefiere hablar de signos linguisticos y signos paralingüísticos. Si bien la distinción daría pie a numerosas objeciones desde la lingüística, pues el lenguaje implica al nivel pragmático con la misma intensidad que los niveles sintáctico y semántico, resulta necesaria para subrayar la diferencia que presenta el teatro frente a los otros géneros literarios, en los que factores como cl tono, la intensidad. el volumen, la articulación, ete., representados por la escritura de forma muy imperfecta, suelen aparecer descritos, mientras que en el teatro hablado son percibidos directamente debido a la presencia física de los actores -sin embargo. en la ópera y las formas afines estos factores suelen desaparecer, siendo sustituidos por los imperativos del canto-. 26. Es una posición comprensible si tenemos en cuenta: 1) que el lenguaje es el medio de expresión y de comunicación más importante de todos aquellos con los que cuenta el hombre, lo que lo convierte en código indispensable cuando la representación sigue criterios de realismo y/o verosimilitud; 2) que la escritura ha permitido conservar una parte considerable de los textos dramáticos desde la Antigüedad, mientras que la música, la danza y la gestualidad șe han perdido irremediablemente. Bien mirado, no es extraño que el drama haya ocupado durante tanto tiempo esa posición de preeminencia, pero eso no es excusa para encastillarse en una posición que, dada la evolución del teatro occidental a lo largo del último siglo, ha quedado claramente obsoleta. 


\section{JUAN CARLOS PUEO}

basan precisamente en la impugnación -un tanto exagerada, en ocasiones- de todo lo que se relacione con el prejuicio logocéntrico.

Para evitar este y otros errores $^{27}$, una clasificación basada en los medios de expresión ha de reconocer una jerarquía de códigos semióticos diferente para cada uno de los géneros implicados, aun cuando todos ellos se sometan a un sistema superior que determina su condición teatral, distinta de la que puede tener cada uno de estos códigos cuando actúa de forma autónoma ${ }^{2 k}$. Partiendo de que los códigos que surgen de la mímica, los gestos y el movimiento de los actores son comunes a todos los géneros teatrales, lo que los coloca en la cúspide de la jerarquía, los diferentes géneros teatrales se definen, como hemos visto, bien por la posibilidad de incluir junto a estos códigos principales al lenguaje y/o a la música, bien por la posibilidad de cxcluirlos, convirtićndolos en códigos secundarios, al mismo nivel que el peinado, el atrezzo, el decorado o los efectos sonoros, cuya presencia no es determinante para la definición de un género -si bien esto no disminuye su importancia en la representación ${ }^{29}-$. De esta manera, el espectador sabe a qué atenerse respecto a la prioridad que debe otorgar a dos sistemas de significación tan complejos como el lenguaje y la música, que determinan en buena parte el sentido global de la obra, el cual ha de ir construyéndose conforme transcurre la representación ${ }^{30}$. Así pues, la clasificación según los medios de expresión atenderá no solo a la presencia o ausencia del lenguaje y la música, también a su situación cn la jerarquía; y los cuatro géneros resultantes quedarán definidos de la siguiente manera:

27.- Derivados muchos de ellos de otro prejuicio no menos dañino que el logocéntrico, y que podria llamarse "escenocéntrico": se trata de ese tulento que ejercen tantos profetas y sacerdotes de las artes escénicus y que consiste en reducir el hecho teatral a lo que ocurre en el escenario durante la representación, olvidando las más de las veces los vínculos que mantiene esta con el mundo exterior al teatro donde tiene lugar. $\mathrm{Y}$ no me refiero únicamente a conceptos como "realismo" $y$ "verosimilitud", sino también al papel que juegan los diferentes códigos visuales y auditivos en la vida cotidiana o en las demás artes, y que, por tanto, no pueden considerarse códigos semióticos autónomos cuando se trasładan al ímbito escénico.

28. - aEn términos concretes, lo que el teatro permite es la teatralización de todas las artes, o sea, que cualquier otra arte pueda integrarse en la realidad teatral. Supone esto que cada arte, para teatralizarse, ha de perder sa autonomía, dejar de ser un arte autónomo para supeditarse a la realidad eseénica. Se exige a cada arte, para integrarse en la escena, una transformación por medio de la cual su especificidad deje de ocupar un lugar prominente, dominante (como cuando se presenta sola, absorbiendo toda la atención del receptor), para ponerse al servicio de la totalidad de la obra, a su sentido general, o a una parte de ella, en un momento o acción concreta. La música, por ejemplo, no entrará en escena para atraer toda la atención sobre sí misma, como realidad artística autónoma, sino en función de la representación, ya sea para potenciar una acción, transformar un ambiente, despertar una emoción, provocar una estimulación concreta, sugerir un espacio, ctc, pero todo ello con relación al momento đramático en el que esa música se integra. No significa esto que la música, en este caso, sea un elemento secundario, innecesario, sino todo lo contrario; se convierte así en uno de los elementos esenciales de la obra o del momento concreto en el que se integra o teatraliza. Lo mismo podriames decir de la pintura, la escenografía, un haile, una danya, una corcografia, un malabarismo, unat canción, un efecto mágico o sorpresivo. Todo cabe en el teatro, decimos, pero con lin condición tautológica de que se tcatralices. (Trancón, 2006: 143; en cursiva en el texto).

29.- Permítaseme insistir en esto, pues mi intención no es quitar protagonismo a unos signos en heneficio de otros. Esta jerarquía solo es pertinente en ctanto sirve para distinguir unos géneros de otros. Por tanto, solo afecta a la representación teatral en la medida en que esta se proponga respetar esta distinción. Si lo que se busca es dinamitar las convenciones genéricas, una de las mejores maneras es sin duda no respetar la jerarquía.

30.- Aplicado a una obra determinada, el esquema proporcionado por la noción del género a que pertenece esa obra funciona como un "manual de instrucciones" para el espectador, un punto de partida con el que enfrentar su tarea de (re)construcción del sentido del texto. El género determina en buena medida su horizonte de expectativas, las cuales pueden verse confirmadas o modificadas, dando lugar asf́ a una nueva idea del género en cuestión, que aplicará nuevamente a la siguiente obra que se le presente con dichas caracteristicas. Como puede verse, no se trata de una cuestión baladí, pues de ella depende parte de la comprensión de que ha de ser objeto la representación. 


\section{¿ES LA ÓPERA UN GÉNERO LTTERARIO?}

- En la pantomima, los códigos principales son únicamente la mímica, los gestos y los movimientos de los actores, mientras que la música y el lenguaje quedan reducidos a la condición de códigos secundarios ${ }^{3 !}$.

- En el ballet, ha de añadirse a los códigos principales la música, que determina la disposición de la coreografía - esto es, mímica, gestos y movimiento-; el lenguaje, en cambio, es un código secundario ${ }^{32}$.

- En el drama, el lenguaje funciona como código principal, unido a la mímica, los gestos y el movimiento de los actores, mientras que la música pasa a ser un código secundarion.

- En la ópera, tanto el lenguaje como la música funcionan como códigos principales con, al menos, la misma importancia que la mímica, los gestos y los movimientos de los actores ${ }^{34}$.

Una ve z ha quedado clara no solo la presencia, también la jerarquía en que se sitúan lenguaje y música en cada uno de los géneros surgidos de la clasificación según los medios de expresión, ha de precisarse que entre cllos siempre existe la posibilidad de realizar diferentes combinaciones según modalidades de representación teatral que siguen las pautas descritas para cada género: así, la representación de una ópera puede incluir ballets -la "Danza de las estaciones" de Las Visperas Sicilianas, o la "Danza de las horas" de La Gioconda-, al igual que un drama puede incluir pantomimas - "El asesinato de Gonzago" de Hamlet-, ballets - la "Danza de los sicte velos" de Salomé- o canciones -"Que de noche le mataron..." de El caballem de Olmedo- ${ }^{35}$. Por su parte, el drama y la ópera han dado lugar a subgéneros mixtos como el Singspiel, la opereta, la zarzuela o la comedia musical, caracterizados por la alternancia de partes habladas, en las que la música forma parte de los códigos secundarios, y partes cantadas, en las que la música se une a los códigos principales.

31.- Aunque al mimo no le está permitido hablar ni cantar, eso no quiere decir que la música no pueda formar parte de la representación acompañando a la acción, como ocurre en la mayor parte de los montajes de este tipo. En cuanto al lenguaje, su presencia es mís infrecuente, unque puede formar parte del decorado designando, por ejemplo, un estabiecimiento comercial, o puede incluirse en la representación como efecto sonoro procedente del espacio fucra del escenario.

32. - Tampoco a los bailarines les está permitido hablar. Pero la presencia del lenguaje en la representación puede manifestarse en has condiciones indieadas en la nota anterior.

33.- Al actor dramático no solo le estí permitido hablar, sino que tiene la obligación de hacerlo -salvo excepciones, como cuando aparece un personaje mudo-, ya que el lenguaje contribuye a que se desarrolle la acción. El canto, en cambio, es opcional: no suele hacer que avance la acción, y no exige una técnica depurada como en la ópera. l.a mésica incidental tampoco es indispensable para la representación, iun cuando haya habido obras notables en este género compuestas por Beethoven, Schuhert, Mendelssohn, Nielsen o Grieg, entre otros muchos.

34.- El altísimo nivel de exigeneia del canto operístico ha impedido durante mucho tiempo que se alcanzassen en la ópera las capacidades desarrolladas por el drama y la pantomima en el dominio de la mímica, los gestos y los movimientos de los actores. Los cantantes de ópera no pueden realizar determinados movimientos que estropearian o imposibilitarían la catidad de su canto. Ocurre también que sus rasgos físicos no se adecuan a los del personaje, de modo que no es extraño que el público operistico se encuentre con una Carmen de rasgos orientales, una Mimí lozana como un roble, $o$ un Werther sexagenario, incongruencias a las que no se ha de dar importancia cuando se contrastan con la excepcional calidad de los intérpretes.

35.- En efecto, el drama es el género teatral más proclive a incluir manifestaciones procedentes de los otros tres géneros, por idiosinerasia y por tradición -véase n. 26-. Pero esto no le otorga una posición de superioridad, ya que las relaciones que mantiene con ellos no implican ninguna modificación en su estatuto genérico: aunque incluya pantomimas, danzas y canciones, el drama sigue siendo el género en que el lenguaje pasa a formar parte de los códigos principales mientras la música se mantiene en el nivel de los códigos secundarios. 


\section{JUAN CARLOS PUEO}

Reconocer en la música un medio de expresión de igual importancia que el lenguaje puede resultar incómodo no solo para quienes pretenden que la ópera es un género exclusivamente musical, sino también para la teoría y crítica literarias acostumbradas a considerar a la ópera como un drama al que, sencillamente, se le ha añadido música sin que cl resultado de tal operación haya desvirtuado en lo más mínimo su condición original de drama hablado. Ahora bien, la pretensión de que la música es un medio de cxpresión neutro, incapaz de añadir algo o modificar de alguna manera el sentido del texto, resulta a todas luces insuficiente. El pensamiento musical se ha caracterizado desde sus inicios por buscar las claves que permitieran determinar el sentido de las obras musicales, y aunque la Modernidad haya modificado la pregunta inicial acerca de qué significa la música para indagar en la naturaleza de los mecanismos semióticos en que se asienta la noción de lenguaje musical, lo cierto es que en ningún momento se ha llegado a la conclusión de que la música no significa absolutamente nada. La cuestión es sumamente compleja, $y$ ha sido objeto de intensos debates que, sin cmbargo, no han llegado a establecer un consenso definitivo cn torno a la cuestión ${ }^{36}$. Tan solo parecen haber sido objeto de un acuerdo al que ya no se le pueden poner reparos algunos puntos previos que resumo a continuación:

- No se puede pretender que la música sea un sistema semiótico de la misma naturaleza que el lenguaje, ni mucho menos que sus significados puedan verbalizarse. Cualquier intento de determinar la naturaleza del lenguaje musical habrá de tener en cuenta su especificidad semióticat ${ }^{37}$.

- La música da lugar, antes que nada, a un proceso de significación que no se refiere a otra cosa que no sea la propia música, su contenido sonoro desplegado en una secuencia de elementos de distinto orden-melódico, armónico, rítmico, tímbrico, etc.- cuyas relaciones son percibidas por el oyente con el fin de encontrar el sentido de la obra en su unicidad ${ }^{38}$.

- En ocasiones, la música tiene la capacidad de imitar otros tipos de sonidos, adquiriendo así el signo musical la condición de icono que va más allá de la autorreferencialidad expuesta en el apartado anterior, si bien la propia iconicidad de estos signos excluye otras referencias que no sean las estrictamente sonoras.

- Aun cuando no se haya llegado a establecer nunca un código o una gramática musicales que determinen la existencia de un lenguaje musical compartido por

36.- El debate ha sido muy intenso durante el pasado siglo y promete serlo en el presente: puede encontrarse una excelente síntesis de las posiciones que se han mantenido en los últimos aỉos en Alonso (2001). Para un panorama histórico más amplio, referido a la cultura occidental en foda su extensión, véase Fubini (1976).

37.- - In a merely linguistic universe -inhabited by writers, philosophers, critics-music is paradoxically mutc, and we undertake to speak for it, to assign it meaning or the lack thereof. Music, for Rousseau, for de Man, for all writers about music, is again dealt with prosopopoeiacally, now by being made a ventriloquist's dummy, who can be made to speak any interpretation. And who would think of arguing with that terrible painted doll who sits on the magician's lap? 7 (Abbate, 1991: 18).

38.- En realidad, esto se peede aplicar a toda obra de arte, independientemente del material con que trabaje. Lo que ocurre es que el debate entre referencialistus y formalistas se basa precisamente en la posición que mantienen ambos partidos hacia esta premisa: así, los referencialistas indican que al significado introversivo, que no hace referencia a otra cosa que no sea su propio ser, se le pueden añadir otros de carácter extraversivo que remiten a conceptos extramusicales; por su parte, los formalistas precisan que el significado introversivo es el único que puede ofrecer la obra de arte musical, por lo que cualquier intento de dar a la música un significado que vaya más allá de su propia fisicidad ha de considerarse una ingenuidad o una estafa. 


\section{¿ES LA ÓPERA UN GÉNERO LITERARIO?}

una comunidad más o menos amplia", existe la posibilidad de que se establezcan asociaciones convencionales de ciertos elementos sonoros con significados extramusicales.

Entre la iconicidad y el convencionalismo -insuficientes para resolver la cuestión de si existe un lenguaje musical- hay un gran espacio de indeterminación que la semiótica musical ha tratado de rellenar sin haber podido, hasta el momento, llegar a conclusiones satisfactorias. Pues aunque no se puede negar la presencia de valores afectivos en la música, el principal problema al que nos enfrentamos reside en la naturaleza semiótica de estos: una obra musical puede provocar sentimientos o estados anímicos de carácter cufórico o disfórico, pero estas reacciones han de situarse en niveles intuitivos o de pre-consciencia, lo que dificulta la aplicación de los esquemas semióticos habituales, ya que no se puede hablar de signos en el sentido usual del término, esto es, como asociación consciente de un significante con un significado $\%$

Todo esto ha de tenerse muy en cuenta a la hora de determinar -en la medida de lo posible- las relaciones entre música y lenguaje, pues en ningún momento se ha de pensar que la presencia de uno es mera adición destinada a intensificar las propiedades del otro: de ser así, la música solo tendría la misión de acentuar los aspectos afectivos del lenguaje, mientras que este se dedicaría a hacer explícito el sentido de las obras musicales. Por el contrario, la combinación de lenguaje y música ha de entenderse como un proceso de compenetración que lleva a ambos sistemas a ofrecer una unidad superior en la que ya no cabe pensarlos separadamente. Evidentemente, la relación entre ambos no siempre se revela equilibrada, pues son numerosos los ejemplos en los que la presencia del lenguaje no deja de ser pura anécdota, comparada con la precminencia dada a la música, que se convierte en la auténtica reina de la función cuando lo lingüístico se limita a ofrecer un título o un programa que, como es natural, solo afectan muy ligeramente a la recepción del oyente -en especial en obras extensas como, por ejemplo, la Sinfonía Heroica de Beethoven-. Sin embargo, ni siquiera en estos casos se debe tomar a la ligera la presencia del lenguaje, cuya huella se mantiene siempre en la conciencia del oyente avisado: hasta la pertenencia de la obra musical a un género determinado puede servir de pista para que el oyente la asocic con un significado que, si bien no es imprescindible para la correcta recepción de la obra, la enriquece expandiendo sus posibilidades. Dicho significado se hace explícito solo con que la obra se adscriba a un género como la serenata, el nocturno, la marcha -militar, nupcial, fúnebre-, la barcarola o cualquiera de los géneros asociados a la danza

39,- Hay que recordar que en los siglos XVII y XVIII se escribieron diversas retóricas musicales en las que sus autores, sigsiendo el paradigma científico de carácter taxonómico propio de la época, se esforzaron por realizar clasificaciones de elementos musicales a los que se podian asociar diversos significados (véase 1.ópez Cano, 2000). El gran problena de estas clasificaciones es que solian responder, más que a un consenso más o menos generalizado, a las impresiones subjetivas de sus autores, lo que, a la postre, inutilizaba todos sus esfuerzos en el mismo momento en que dichos autores se veían despojados del principio de attoridad.

40, $-\alpha$ El fundamento psicológico perceptivo de todos estos valores afectivos, que percibimos como inmanentes a la forma, parece estar en la proyección de ciertos estados emocionales del oyente sobre el material musical, a través de la evocación de determinados estados psico-fisiológicos, por una identificación entre las circunstancias que los producen y aquellas que estructuran la experiencia perceptiva de la música. I.o interesante es saher qué parte de la experiencia emocional y afectiva del sujeto, de sus estados psicológicos, es susceptible de ser tratada por la música, de ser evocada. Y lo más difícil es precisar de qué modo se lleva a cabo esar correspondencia entre sentimientos y sonidos. Parece claro [...] que el contenido vivencial que comportan las percepciones asociadas a estados psicológicos no es algo innato sino producto de un proceso de abstracción que, no obstante, tiene hugar en un nivel pre-consciente, $y$ se establece sobre la base de las impresiones corporales asociadas a esos estados. Se trata, por así decirlo, de una analogía, más compleja que una simple copia o imitación, entre esquemas afectivos y esquemas de fa inteligencia sensorial y la inteligencia intuitiva. Junto a una comprensión lógica y racional del estaরio psicológico en cuestión, hay una comprensión intuitiva de tal estado que complementa a la anterior pero que es esencialmente diferente, a pesar de recubrir el mismo objetos (Gonvález, Martínez, 1999; 122). 


\section{JUAN CARLOS PUEO}

-vals, mazurca, pavana, minueto, ctc. ${ }^{44}$. El desequilibrio entre lenguaje y música también puede darse a la inversa, como ocurre con la música incidental destinada a acompañar algunas secciones del drama hablado ${ }^{42}$.

El equilibro, en cambio, se da en toda su plenitud cuando lenguaje y música se fusionan en el canto, formando así una unidad indisoluble en la que ambos resultan imprescindibles, sistema privilegiado que aúna - 0 , al menos, eso intenta- la poderosa capacidad afectiva de la música con la no menos poderosa capacidad significativa del lenguaje ${ }^{43}$. Es verdad que ambos pueden separarse y dar lugar a formas de recepción diferentes de la que resulta de su unión ${ }^{44}$, pero no es menos cierto que en cstos casos lo que se recibe es un texto muy diferente, en el que, obviamente, ya no se pueden encontrar las características derivadas del vínculo que se establece por medio del canto. Esto se hace evidente cuando aplicamos al texto resultante la noción de autoría, de la que hacemos depender-siguiendo el esquema que nos hace buscar la causa de un efecto- buena parte de su sentido: así, el texto literario de Goethe "El rey de los elfos" pasa a ser el texto musical del mismo nombre de Schubert, aunque esto no implique la pérdida de autoridad por parte del poeta, a quien se considera co-responsable del texto final resultante. Pretender separar en el canto lo literario de lo musical apelando a la especificidad de ambos lenguajes solo puede ser resultado de la estrechez de miras de quien se empeña en mantener divisiones que pueden resultar metodológicamente útiles para una visión general del hecho artístico - nadie discute que música y literatura son artes de naturaleza, métodos y

41. Indudablemente, esto no ocurre cuando la denominación genérica es voluntariamente neutra o alude ủnicamente a procedimientos constructivos, como ocurre con géneros más comunes como la sonata, el cuarteto, la sinfonía, el concierto, la cantata, y también, por supuesto, la ópera - que, como bien se sabe, quiere decir "obra" en italiano -

42. Siempre pucden existir formas de recepción literaria de carácter espectacular que se acompañen de música instrumental -por ejemplo, un recital poético en el que se interpretase el Prefudio a la siesta de un fauno antes de recitar el poena de Mallarmé-, pero no dejan de tener un valor anecdótico, acotado por lo efímero del acto en que transcurren. No obstante, al igual que en el caso de las formas musicales en las que el lenguaje ha dejado su huella, se puede decir lo mismo en lo que se refiere a las obras literarias que han tenido la fortuna de hallar un compositor lo suficientemente genial para dejar su improata en ellas. Se pecde pensar en el Peer Gynt de tbsen sin recordar la música de Grieg, e incluso se puede asistir a una representación que prescinda de ella: el sentido global de la obra no sufrirá por ello, pero el receptor perderá una oportunidad única para enriquecer la experiencia estétiea que promueve dicha obra.

43, - [... ] el hombre no accede a lo real más que por mediación de un conjunto de sistemas significanles (la lengua, pero también el mito, los ritos, los sistemas de parentesco, los sistemas económicos, el arte) que imponen cada uno su marca a lo real, por el hecho mismo de su estructura y de las condiciones de su funcionamiento, y así queda siempre irreductible, al mismo ticmpo que se vuelve irreductible, en último término, a los otros sistemas significantes, a pesar de las relaciones de equivalencia o de transformación que podemos establecer entre sus respectivas estructuras [..... En el conjunto de estos sistemas significantes, algunos (sobre todo en el arfe y la religión) tienen por principal función precisamente intentar llenar, o enmascarar, el vacío en cuestión. Lévi-Strauss nos ha dado ejemplos en su análisis de la noción de Maná, y también en su estudio sobre las relaciones entre mito y rito. Podriamos preguntamos si la música vocal no representa un caso privilegiado en el interior de esta categoria de sistemas, en la medida en que unifica en una temporalidad única dos sistemas muy diferentes. "Ll lenguaje es lo más verdadero", decía Ifegel, pero el lenguaje separa, aisla, desplaza, y al final siempre quiero una cosa distinta de lo que digo. "La música expresa la pura vida interior", dice Boris de Schloczer, pero es incapaz de nombrat, Comprendemos asf lo que hay de seductor en una actividad que, combinando las dos en una fusión intima, gracias al intermecliario de su órgano común, la voz, intenta dar la ilusión de que una de ellas vendra a llenar el vacio que hay en la otra, y a la reciprocas (Ruwet. 1972: $91-92)$.

44.- Caso muy frecuente en la poesía, no solo porque hasta el siglo XIX se cscribiera bajo la convención de estar destinada al canto, sino porque todavia hoy es habitual la práctica de publicar libros con letras de canciones, verdaderos poemas con las mismas características genéricas que puedan presentar los contenidos en ese tipo de poesía que solo se conoce por medio de la imprenta, y que es tenida por más "seria" por los críticos literarios al uso. Tampoco es extraña la costumbre de presentar versiones instrumentales de obras musicales destinadas en un principio al canto, incluso entre compositores cultos como Schubert of isat. 


\section{¿ES LA OPERA UN GÉNERO LITERARIO?}

objetivos muy diferentes-, pero que en otras ocasiones se convierten en barreras que es preciso trasponer si se quicre llegar a una comprensión acreditada y legítima del objeto de estudio en cuestión $n^{\text {ss }}$,

Pero volvamos nuevamente al tema planteado al principio: como género literario, la ópera -así como los subgéneros afines- ha de cntenderse como texto de naturaleza dramático-musical, con todas las implicaciones que ello conlleva. Su naturaleza teatral está por encima del elemento musical o el elemento literario, los cuales se unen en el canto para expresar el conflicto dramático que ha de exponer toda representación. Es evidente que no puede prescindir del canto, pues sin la asociación de música y lenguaje, la ópera dejaría de serlo para convertirse en otro género -pantomima, ballet, drama, elfjase el que convenga-. Ahora bien, el valor del canto reside en su adecuación a las situaciones dramáticas en que participa, y en las que también ha de tenerse en cuenta el concurso de los restantes signos teatrales: para que cl canto realice plenamente su función dramática necesita del soporte físico del actor-cantante, con todos los signos visuales a él asociados -mímica, gestos, movimiento, máscara ${ }^{4 t}$, vestuario y peinado-y también los signos que determinan el espacio en que se mueve-escenario, accesorios, iluminación, y también los efectos sonoros-. Sin el concurso de todos estos signos, organizados en un espectáculo teatral, tampoco se puede hablar de ópera en un sentido estricto: el resultado podrá adscribirse a los géneros musicales oratorio o cantata, pero no al género ópera. Pues, ¿qué necesidad habría de montar una costosa representación teatral cuando para acceder a los contenidos musicales y/o literarios bastaría con una versión en concierto, una grabación discográfica o la simple lectura del libreto?

Como ya indiqué arriba, no hay ningún impedimento para la recepción estrictamente musical de una ópera, recepción que no atenderá al sentido propiciado por el lenguaje y/o por los signos de carácter visual que ofrece la representación. Sin embargo, el precio que habrá de pagar el receptor será la renuncia a la atribución de significado a una música que retorna así a su pureza originaria, despojada de cualquier capacidad significativa para expresarse solo a sí misma, tal como queria Eduard Hanslick: en efecto, si recordamos el argumento expuesto por quien fuera el primer defensor de la asemanticidad musical, el texto del aria de Orfeo y Eurfdice que dice «J'ai perdu mon Eurydice / Rien n'égale mon malheurs puede alterarse para que diga \&J'ai trouvé mon Eurydice / Rien n'égale mon bonheurs sin que la forma musical varie lo más mínimo ${ }^{47}$. Ahora

45.- ¿Hahré de indicar que mi intención no es, de ninguna manera, establecer la superioridad de un arte sobre el otro? Me temo que sí, e igualmente habré de declarar que tampoco se trata de deslegitimar los estudios musicolígicos en beneficio de los literarios - 0 a la inversa-. Tan solo se trata de dejar bien claro que ninguno de los dos paede olvidarse del otro, que cuando se trata de estudiar un objeto en el que ambas artes mantienen relaciones estrechas, lo que no se puede hacer es dejar a una de ellas de lado como si fuese una adherencia superflua a la que no hay que hacer mucho caso. Pecado del que son culpables buen número de criticos literarios y uma cantidad similar de criticos musicales.

46.- Quede hien claro que no me refiero al artefacto que busca cubrir la cara del actor, cuyo uso en la ópera solo serviria para estropear la articulación y la recepción del canto, sino al aspecto físico, modificado o no, del cantante -véase n. 21-. capaz de generar signos teatrales denotadores de significados especificos: no solo la raza de Otclo, la deformidad de Rigoletto, ete, también aquellos que vienen indicados por la tesitura a que se ha asignado el personaje, como la edad de Cherubino o la de Don Bartolo.

47.- Hanslick (1854: 34) atribuye la observación a un contempxoríneo de Gluck llamsudo Boyé, pero la presenta para reforzar su argumentación soboe la música vocal: aLa misica vocal ilumina el dibujo del poema. Hemos reconocido en los elementos musicales coloxes de la mayor suntuosídad y delicadeza y, ademák, de significación simbolica. Transformaúa quizís un poema mediocre en revelación intima del corazón. Con todo, no scon los sonicks los que representan en una picza de canto, sino que lo es el texso. El dibujo y no el colorido es lo que determina el objeto representado. Apelamos a la capacidad de abstancción del oyente para que se imagine una melodía de efecto dramático cualquiera aislada de todo destino literario, de un modb exclusivamente musical. En una melkodía dramática muy efectiva que tenga que expresar la ira, por ejemplo, no se hallará más expesión psíquica que la de un movimicnto rápido y apasionado. Y es posible que la mísma melodít interprete con el mismo aciento palaboras de un anor apasionadamente excitado, es decir, el sentimiento diametralmente opuestow (Hansfick, 1854: 33). 


\section{JUAN CARL.OS PUEO}

bien, no puede decirse to mismo respecto a la perturbación que imprimiría tal cambio en el sentido de la ópera, dado que el espectador informado no solo acaba de ver caer fulminada a Eurídice, también sabe que Orfeo no podrá volver a buscarla por segunda vez. En el espectáculo teatral, la menor variación de los elementos que aparecen en escena implica un cambio de significado, pero esto es porque todos estos elementos tienen un valor semiótico al que no pueden escapar ${ }^{48}$, incluyendo a la música, cuya capacidad significativa se ve fuertemente incrementada por su alianza con los restantes signos que participan en la representación. Más aún, el protagonismo del canto -entendido siempre como simbiosis de lenguaje y música-, que en la ópera se coloca siempre por encima de los restantes códigos teatrales, es el que determina, como se ha visto, su principal diferencia respecto a otros géneros dramáticos.

Los valores afectivos que provee el canto hacen del teatro musical un medio perfecto para apelar a la sensibilidad del receptor. La ópera va más allá del drama hablado al dirigirse al espectador de forma directa, haciéndole participar en las situaciones y los conflictos dramáticos de una manera en que ya no solo cuenta su comprensión intelectual de lo que está viendo y oyendo, sino también esa forma de participación, característica de la experiencia estética, que consiste en la interiorización de lo que hasta entonces era percibido como ajeno hasta el punto de convertirlo en vivencia propia ${ }^{49}$-pequeño milagro que puede producirse a través de otras formas artísticas, pero no tan intensamente como en la música--. No es extraño que el teatro musical se haya caracterizado por su apelación a la sentimentalidad más apasionada del espectador ${ }^{50}$, hasta el punto de que lo que en principio fuc un término para designar cierto género de teatro musical, el melodrama, haya pasado a extenderse a todo tipo de creaciones en las que se intenta excitar la sensibilidad del receptor por medio del patetismo más exaltado ${ }^{51}$. También es verdad que la preeminencia del canto dificulta en ocasiones el desenvolvimiento de otros signos, que deben adaptarse a sus exigencias: así, los movimientos de los actores-cantantes no pueden ser bruscos, la mímica facial ha de abandonar toda pretensión de verosimilitud para que estos puedan emitir la voz de forma adecuada, los

48. "FI teatro en la última de las fases de su proceso de comunicación, es decír, en la representación, es fundamentalmente una práctica semiótica muy intensa, una "máquina cibernétiea", según expresión de R. Barthes, que convierte en signo todo lo que pone en escena; se puede afirmar que el teatro, como espectáculo, es una actividad totalmente semiótica: todo lo que está en el escenario, y por el mero hecho de estar alli, y todo lo que se realiza en escena, y por el mero hecho de realizato alli, puede ser interpretado por los espectadores como signo y puede ser integrado en la unidad de sentido global de una lecturas (Bobes Naves, 1997: 114-115).

49. - « ... J los usos de la voz son rasgos fundamentales de la autodefinición de un sujeto individual en interacción con otros sujetos y con el mundo circundante. La historización de la ópera de acuerdo con sus distintos modos de dar voz a realidades suprasensibles, pues, será asimismo una historia de la expresión y los modelos de subjetividad cambiantes del género. La voz operística proporciona uni convincente historia capsular de la realización de estas subjetividades cambiantes en la cultura expresiva occidental. Al establecer las fronteras entre los sentidos y lo suprasensible, toca las expectativas subjetivas más profundas de los estratos elitistas de la sociedad occidental que la creó y apreció. Para estos estratos de la seciedad, la voz operística, entre otras fuerzas, sitúa al sujeto en el mundos (Tomlinson, 1999: 12-13).

50.- ${ }_{\text {Ein la }}$ ópera, el lenguaje recibe un tratamiento muy distinto al de su modalidad racional y científica, pues es conducido y modulado por la línea musical, que lo aproxima al cuerpo y a los afectos, lejos de la asignación precisa y diferenciada del pensamiento lógico secundarion (Castarède, 2002: 58).

51.- Melodramma fue uno đe los nombres que se dio en Italia a la ópera cuando el género todavía no estaba suficientemente delimitado y competia con denominaciones como favola in musica, attione in mussica, dramma musicale y la que triunfó finalmente, opera in musica. Poco a poco, el término "melodrama" pasó a referirse a las formas populares de teatro en las que se alternaban partes habladas con partes cantadas, hasta que al final quedó genéricamente caracterizado no por su forma, sino por su contenido, de orientación eminentemente popular, hasta el punto de extenderse a otros dominios artísticos como el cinematográfico. 


\section{¿ES LA ÓPERA UN GÉNERO LITERARIO?}

efectos sonoros han de emplearse de forma que no interrumpan ni se superpongan al canto, etcétera ${ }^{52}$.

Es evidente, entonces, que en la ópera, al igual que sucede con los restantes géneros teatrales, el lenguaje no tiene el protagonismo absoluto que sí tiene en la novela o en el ensayo. Cualquier clasificación genérica, pues, que quiera incluir a la ópera y a las formas afines habrá de tener en cuenta su carácter músico-literario, entendido no como disminución de las potencialidades de ambos, sino como enriquecimiento. Ciertamente, tal actitud se opone a la de las diferentes clasificaciones genéricas que se han ofrecido a lo largo del siglo XX -algunas más deudoras que otras del esquema aristotélico-, las cuales suelen dar a la ópera, si es que se animan a hacerle un hueco, un carácter marginal ${ }^{53}$. Porque tampoco se ha de olvidar que toda clasificación de géneros literarios es producto de una noción más o menos restrictiva de lo que puede y no puede ser literatura dentro un conjunto mucho más amplio, el de los géneros del discurso ${ }^{4}$. Desde el prejuicio logocéntrico, una clasificación de géneros según los medios de expresión puede considerarse poco o nada pertinente, por lo que se hará necesario colocar todo aquello que se salga de los límites establecidos por el logocentrismo en un espacio fronterizo, a medio camino entre los géneros plenamente literarios y otras formas de discurso de carácter no lingüístico.

Se ha intentado solucionar el problema apelando a la literatura comparada, uno de cuyos negociados se ocupa precisamente de las relaciones - de la iluminación, dicen algunos- entre la literatura y las demás artes. El prejuicio logocéntrico queda a salvo mediante la creación de una categoría tangencial, la de las "formas mixtas", en las que lo literario se combina con otros lenguajes estéticos para producir un sentido que ha de inferirse no de la yuxtaposición -como pretenden quienes todavía siguen reduciendo el comparatismo a estudios de influencia y recepción-, sino de la conjunción de todos sus elementos. Pero, en realidad, dicha categoría no es más que un cajón de sastre en el que cabe todo lo que incomoda a la teoría y la crítica literarias por considerarlo una

52. Téngase en cuenta, sin embargo, que lo único que han producido estas y otras restricciones -véase n. 34 ha sido un alto grado de convencionalismo en la representación operística que no ha menoscabado de ninguna manera su condición teatral: los signos involucrados en las representaciones de otros géneros como la pantomima o el ballet presentan un grado de convencionalidad no menos elevado; ni siquiera el drama hablado puede presumir de estar siempre libre de convencionalismos, por más que el prejuicio naturalista pretenda lo contrario.

53.- Así ocurre con una de las clasifieaciones genéricas que más interés han despertado, la ofrecida por Northrop Fírye en su Anatomía de la críica (1957: 381-384), donde se especifica que la ópera es una derivación del género mascarada-resulta evidente que Frye tiene en cuenta sobre fodo la tradición anglosajona- - en que el espectáculo busca la exaltación participativa por medio de la música y la danza de un ideal en el que el público se reconoce y participa. La ópera, sin embargo, se diferencia de la mascarada en su intención de imitar por medios espectaculares un género que se halla en las antípodas de la mascarada, el drama mimético en el que lo importante son los acontecimientos y sus causas -la trama-. Con todo, la presencia de la música marca a la ópera manteniéndola en la órbita de la mitscarada: $\alpha$ La mascarada ideal concede al póblico una situación de superioridad respecto al descubrimiento. La acción verbal de Figaro es cómica y la de Don Giowanni trágica; pero en ambos casos la música exalta al público fuera del alcance de la tragedia y de la comedia, $y$, aunque quede tan profundamente conmovido como siempre, no se encuentra emotivamente afectado por el descubrimiento de la trama o de los personajes. Contempla ta caida de Don Juan como un espectículo entretenido, tal como se supone que los dioses contemplan la caída de Ayax o de Darion (Frye, 1957: 383).

54.- $\alpha$ La constitución del género depende estrechamente de la estrategia discursiva del metatexto (por consiguiente, del teórico de la literatura); es él quien elige, al menos en parte, las fronteras del género, él quien clige el nivel de abstracción de los rasgos que seleccionará como pertinente, y él, finalmente, quien elige el modelo explicativo (y este último punto es decisivo, puesto que atañe al estatuto concedido a la genericidad: el modelo estructuralista, por ejemplo, es mucho más poderoso que un modelo historicista: el género, en él, tendrá tendencia a constituirse en auténtico modelo de competencia). Está claro que, en cuanto a la clase de textos seleccionada, nos encontramos con simples parecidos de familia, Familienänhlichkeiten, por decirio con las palabras de Wittgenstein. La estrategia discursiva del teórico se ejerce sobre esta base; es decir, actualmente al menos, la elaboración de un modelo de competencia que permita generar los invariantes textuales* (Schaeffer, 1983: 174). 


\section{JUAN CARLOS PUEO}

intrusión de elementos no lingüísticos en el ámbito de "lo estrictamente literario". El objetivo, que no es otro que el de arrumbar dichas formas a un rincón donde no molesten demasiado, se cumple perfectamente dándoles un carácter marginal que convierte a sus defensores en auténticos profetas clamando en el desierto"s.

A decir verdad, desde un planteamiento serio de la teoría de los géneros literarios solo se puede concluir que el recurso a estas "formas mixtas" ofrece más problemas que soluciones. Habría de realizarse una clasificación que tuviese en cuenta todas las posibilidades de combinación de lo literario con códigos no linguísticos, sin tener en cuenta que existen formas como el cine o el cómic que han desarrollado una teoría y una crítica propias, de manera que lo literario aparece, al igual que ocurre con la ópera, subsumido en un sistema mucho más complejo al que no se puede acceder con los instrumentos críticos que se emplean al abordar la novela o el ensayo -dejo al margen la poesía lírica porque no siempre se ha destinado a la lectura en solitario--. Se podría incluso plantear una cuestión que incomodaría todavía más a los defensores del logocentrismo, hasta llevarles a altos niveles de indignación colérica: si las "formas mixtas" son aquellas cn las que lo literario se involucra junto a otros códigos no linguísticos, ¿qué es lo que impide al teatro dejar su lugar junto a los géneros canónicamente literarios y pasar a formar parte de estas "formas mixtas", dado que está demostrado que el teatro solo es objeto de una recepción adecuada cuando se logra por medio del texto espectacular?

Pero no es necesario llegar a esos extremos. Tan solo se necesitaría modificar la perspectiva con que se enfoca el sistema tradicional de los géneros para dar cabida a aquellos en los que también participan otros medios de expresión. La teoría de la literatura ha estado insistiendo en cllo durante mucho tiempo al estimar que su objeto de estudio no era otro que la literariedad, esa peculiar condición que hace de un mensaje linguístico un texto especial al que se denomina y se caracteriza como literario, independientemente del contexto en el que surja, acompañado o no de signos procedentes de otros códigos. La teoría de los géneros, consiguientemente, no ha podido menos que hacerse eco de estas tesis, pero todavía existen reticencias para aceptar la posibilidad de que lo literario vaya acompañado por otros signos: la clasificación de las artes parece haberse quedado anclada en un ideal de pureza que no permite la "contaminación" por otros medios que no sean los establecidos para cada arte. Prejuicios academicistas destinados a guardar las fronteras de disciplinas que se querrian compartimentos estancos: la práctica artística, por el contrario, viene caracterizándose desde el primer momento por el enriquecimiento que supone el contacto y la simbiosis con otras formas. Y si la pertinencia del esquema genérico propuesto ha quedado suficientemente demostrada a lo largo de estas páginas, quedaría además pendiente de demostración una segunda condición que la establecería de forma concluyente: la existencia de una tradición que permitiera fijar la evolución histórica de los géneros dramáticos. Pero eso es otra historia: es más, es una historia.

55.- Tampoco quiero negar en modo alguno que me parece que precisamente la parte más provechosa de todo este ámbito limitrofe de la ciencia compurada de la literatura es cabalmente el campo de las formas mixtas, cuya investigación es sospechosa a muchos científicos "puros" de la literatura, ante todo por motivos prácticos. Suele decirse que en formas como la ópera (incluyendo la opereta y el musical), el oratorio, la canción artística, el ballet. el cine, el emblema y la historia en imágenes (hasta los cartoons) no participa exclusivamente la literatura, y que para no sucumbir al diletantismo, el cientifico de la literatura no debe ocuparse con tales cosas. Así, precisamente los géneros como la ópera o el canto artístico han sido concebidos como campos de trabajo genuinamente musicológicos, aunque los textos correspondientes analizables científica-literariamente son partes constitutivas de las obras de estos géneros. Evidentemente, aquí se nota, en no poea medida, una cierta comodidad de científico de la literatura, que no desea desarrollar su interés en la música hasta lograr una cierta competencia musicológica mediante los correspondientes estudios especiales. Lo mismo puede decirse con respecto a la ciencia del artex (Schmitt-von Mühlenfels, 1981: 182). 


\section{¿ES LA OPERA UN GÉNERO LITERARIO?}

\section{Bibliografía citada}

Abbate, Carolyn (1991): Unsung Voices: Opera and Musical Narrative in the Nineteenth Century. Princeton, Princeton University Press.

Alonso, Silvia (2001): Música, literatura y semiosis. Madrid, Biblioteca Nueva.

- , comp. (2002): AA. VV., Mísica y literatura. Estudios comparativos y semiológicos. Madrid, Arco.

Bentley, Eric (1964): La vida del drama. Trad. Alberto Vanasco. Buenos Aires, Paidós, 1982.

Bobes Naves, M. ${ }^{2}$ del Carmen (1981): "Posibilidades de una semiología del teatro", en Bobes Naves, comp. (1997), pp. 295-322.

- (1987): Semiología de la obra dramática. Madrid, Arco, 2." ed., corregida y ampliada, 1997.

— (1988): Estudios de semiología del teatro. Valladolid-Madrid, Aceña-La Avispa.

- comp. (1997): AA. VV., Teoría del teatro, Madrid, Arco.

Bobes Naves, M." del Carmen, et al. (1995): Historia de la teoría literaria, 1: La Antigïedad grecolatina, Madrid, Gredos.

Castarède, Marie-France (2002): El espiritu de la ópera. La exaltación de las pasiones humanas. Trad, Julià de Jodar. Barcelona, Paidós, 2003.

Derrida, Jacques (1980): "La loi du genre", en Parages. París, Galilée, 1986, pp. 249-287.

Fischer-Lichte, Erika (1983): Semiótica del teatro. Trad. Elisa Briega Villarrubia. Madrid, Arco, 1999.

Frye, Northrop (1957): Anatomía de la crifica. Trad. Edison Simons. Caracas, Monte Ávila, 2." ed., 1991.

Fubini, Enrico (1976): La estética musical desde la Antigüedad hasta el siglo XX. Trad. Carlos Guillermo Pérez de Aranda. Madrid, Alianza, 1999.

García Barrientos, José Luis (1981): "Escritura / Actuación. Para una teoría del teatro", en Bobes Naves, comp. (1997), pp. 253-294.

García Yebra, ed. (1974): Aristóteles, Poética. Madrid, Gredos.

Garrido Gallardo, Miguel Ángel, comp. (1988): ^A. VV., Teoría de los génenos literarios. Madrid, Arco.

Genette, Gérard (1979): Introduction à l'architexte. París, Seuil.

González Martínez, Juan Miguel (1999): El sentido en la obra musical y literaria. Murcia, Universidad de Murcia.

Hanslick, Eduard (1854): De lo bello en mísica. Trad. Alfredo Cahn. Buenos Aires, Ricordi, 1947.

Kowzan, Tadeusz (1968): "El signo en el teatro: introducción a la semiología del arte del espectáculo". Trad. M." del Carmen Bobes y Jesús G. Maestro, en Bobes Naves, comp. (1997), pp. 121-153.

- (1970): Literatura y espectáculo. Trad. Manuel García Martínez. Madrid, Taurus, 1992.

Llovet, Jordi, et al. (2005): Teoría literaria y literatura comparada. Barcelona, Ariel. 


\section{JUAN CARLOS PUEO}

López. Cano, Rubén (2000): Música y retórica en el Barroco. México, Universidad Nacional Autónoma de México.

Pavis, Patrice (1996): Diccionario del teatro. Trad. Jaume Melendres. Barcelona, Paidós, 3., ed. revisada y ampliada, 1998.

Ruwet, Nicolas (1972): "Función de la palabra en la música vocal". Trad. Silvia Alonso, en Alonso, comp. (2002), pp. 63-92.

Sánchez Montes, María José (2004): El cuerpo como signo. La transformación de la textualidad en el teatro contemporáneo. Madrid, Biblioteca Nueva.

Schaeffer, Jean-Marie (1983): "Del texto al género. Notas sobre la problemática genérica", Trad. Antonio Fernández. Ferrer, en Garrido Gallardo, ed. (1988), pp. 155-179.

Schmeling, Manfred, dir. (1981): Teoría y praxis de la literatura comparada. Trad. Ignacio Torres Corredor. Barcelona-Caracas, Alfa, 1984.

Schmitt-von Mühlenfels, Franz. (1981): "La literatura y las otras artes", en Schmeling, dir. (1981), pp. 169-193.

Tomlinson, Gary (1999): Canto metafísico: un ensayo sobre la ópera. Trad. T. Paul Silles. Barcelona, Idea Books, 2001.

Trancón, Santiago (2006): Teoría del teatro. Bases para el análisis de la obra dramática. Madrid, Fundamentos.

Ubersfeld, Anne (1977): Semiótica teatral. Trad. Francisco Torres Monreal. Madrid, CátedraUniversidad de Murcia, 1989.

Viñas Piquer, David (2005): "Los géneros literarios", en Llovet et al. (2005), pp. 263-331. 